\title{
Socio-Cultural History of the Gond Tribes of Middle India
}

\author{
Shamrao Koreti
}

\begin{abstract}
This Paper highlights the socio-cultural History of the Gonds of Middle India (Gondwana) since $17^{\text {th }}$ to mid $20^{\text {th }}$ century. The four major Gond kingdoms which ruled over Middle India were i.e. Garha Mandla (1300 AD. to 1789AD), Deogarh (1590 AD to 1796AD), Chanda (1200 AD to 1751 AD) and Kherla (1500 AD to 1600 AD). The Garha-Mandla Kingdom in the north extended control over present Chhattisgarh \& Madhya Pradesh. The Deogarh-Nagpur kingdom dominated over Nagpur plains. While Chanda-Sirpur covered parts of old Chandrapur \& Bhandara District. Kherla lies in Satpura terrains. They maintained a relatively independent existence until the middle of the eighteenth century. The Gonds were the major tribes in Middle India. Gonds were subdivided into Raj-Gonds, Khatola-Gonds, Madia Gonds, Dhur Gonds, Dadve Gonds, Mokasi Gonds, Gaita Gonds, and Koyas etc. The ruling class among the Gonds was known as Raj Gonds. The Raj Gonds were the direct descendants of those dynasties which ruled over Middle India. The above mentioned kingdoms developed their social, religious, and cultural history during those long years. Each of these Gond Raja kingdoms separately passed through three successive stages: the first one of comparatively peaceful expansion and consolidation; the second of contact with Mughal emperors or their subordinates and nominal allegiance to the Mughal Empire; and the third of internal dynastic struggles which eventually resulted in Maratha intervention. This intervention defiles the ethnic and cultural identity of the Gonds in middle India. With the advent of new rulers and changed circumstances the Gond rulers could not hold the kingdoms, but socio-cultural history remains unchanged till the date.
\end{abstract}

Index Terms-Animism, Gondwana, Gotul institution, Raj-Gonds.

\section{INTRODUCTION}

Tribal societies are the earliest known societies in human history. Though there is hardly any clear mention of tribal societies in ancient times we get mentions of some groups of people in epics and other ancient literature who have often been depicted as Rakshas (devil), Ashuras (demons), Dashyus (robber) and even Banors (monkeys). According to 2011 census, the Tribes of India account for 109 million and represent 8.6 percent of the country's total population. Article 342 of the Indian Constitution includes a schedule (list) of the Tribal communities that are economically and socially disadvantaged. Among these tribes the Gonds are the largest number in Middle India (Gondwana). Gonds were subdivided into Raj-Gonds, Khatola-Gonds, Madia Gonds, Dhur Gonds, Dadve Gonds, Mokasi Gonds, Gaita Gonds, and Koyas etc. The ruling class among the Gonds were

Manuscript received October 29, 2014; revised December 30, 2014.

Shamrao Koreti is with the Post Graduate Teaching Department of History, Rashtrasant Tukadoji Maharaj Nagpur University, Nagpur Maharashtra, India (e-mail: shyamkoreti@gmail.com). known as Raj Gonds. Gonds are essentially a primitive tribal community involved in hunting and food gathering, pastoral occupations, agriculture, martial assignments, basic trade and commerce, herbal medicine as well as rulers in Middle India, etc. At the same time they have perpetuated a unique tribal culture and language affiliation depending on the geographical regions. This tribal unique speciality merits a better exposure and analysis to effect satisfactory assimilation into the social mainstream.

According to 2011 census Gonds, the major tribe of the country has been notified as scheduled tribe in the following states: Andhra Pradesh, Bihar, Chhattisgarh, Gujarat, Jharkhand, Karnataka, Madhya Pradesh, Maharashtra, Odisha, Uttar Pradesh, Uttaranchal and West Bengal having a total population of $1,13,44,629$. They are concentrated in the middle region, popularly known as Gondwana, which includes the Satpuda Plateau, a portion of the Nagpur plain area and the Narmada Valley and are believed to belong to the Dravidian stock. This tribe has a share of 13.45 per cent of the total scheduled tribes' population of India. So far as the percentage of Gonds to the total scheduled tribes population of state is concerned, Madhya Pradesh shows the highest percentage (43.69\%), followed by Maharashtra (19.47\%), Odisha (9.97\%), Karnataka (6.47\%), Andhra Pradesh $(5.04 \%)$ and Bihar (1.57\%) [1].

\section{HISTORICAL BACKGROUND}

The first historically recorded Gond kingdoms came up in middle India's hilly region in the 14th and 15th century AD. The first Gond king was Jadurai, who deposed the Kalchuri Rajputs to grab the kingdom of Garha Mandla (1300 to 1789 AD). The second kingdom of Deogarh was created by King Jatba in 1590 AD which lasted till 1796 AD. Around the same time as Deogarh, the Kherla kingdom also came up in $1500 \mathrm{AD}$ and remained for a century. Its first king, Narsingh Rai, who deposed a Rajput ruler, had love-hate relationship with the Rajput and Muslim rulers in his vicinity that attacked his fort due to its geographical accessibility. The Chanda kingdom (1200 to 1751 AD), a contemporary of the Kherla and Deogarh kingdoms, produced several remarkable rulers who developed excellent irrigation systems and the first well defined revenue system among the Gond kingdoms [2].

Each of these Gond Raja kingdoms separately passed through three successive stages: the first one of comparatively peaceful expansion and consolidation; the second of contact with Mughal emperors or their subordinates and nominal allegiance to the Mughal Empire; and the third of internal dynastic struggles which eventually resulted in Maratha intervention and gradual decline of Gond kingdoms. [3] Later they were overwhelmed by British forces. Maratha rule over Nagpur and Chhattisgarh had 
ended inauspiciously in $1854 \mathrm{AD}$. This was a period of transition for the middle India, which was initially ruled by Maratha power in 18th century and later in 19th century followed by the mighty Britisher's. These ascendancies made tremendous change in the political, social and economic scenario and defile the identity of Gondwana permanently. However, the Gonds ruled over a large kingdom of middle India for many centuries and had developed their own social, religious, and cultural base during those long years. The researcher has tried to reveal the same through social, religious, and cultural aspects of the Gonds.

\section{SOCIAL LIFE OF THE GONDS}

The social institutions of the Gonds have been undertaken here in relation to functional aspects of the social organizations having both vertical and horizontal dimensions. The social organization primarily deals with the significant grouping of individuals. Social organization usually has been taken as synonym for social structure. The Gond community was a vast and widely spread. It was divided into number of sections which differed in their nature. These sections were ordinarily endogamous and consisted of clans that were grouped into exogamous phratries within them.

\section{A. Gond Family}

Family was the smallest social unit. The Gond family was a unilateral social group consisted mainly of parents and their children both male and female. [4] Only unmarried daughters were regarded as members of the family. However, in the recent past the joint family system is fast disappearing and individual family system took its place. The Gonds used the term 'pari' to express their group. The clan among the Gonds was a unilateral group consisted of family members of which bear the same clan-name. Members of the clan believed that they have been descended from a common ancestor. The clan being patrilineal a man passes on his clan name to his children. A woman kept her father's clan-name till she was married. All the same a married woman was not regarded as a member of her father's clan. It was only the male who automatically takes the patronymic on birth, preserved it till death and transmits it to his children. It's a permanent feature of the Gond community.

\section{B. Class and Caste}

There were numerous class and caste groups known by different names among Gonds. The member of both a class and a caste was determined by birth, and an individual was considered to belong to the class or caste of his or her father. The segmentary characteristic of the Gond tribe have withered considerably in the light of caste-organization. Now the Gonds have a very high appreciation of caste, and strongly claim their position as equal to that of the higher castes in the country. Likewise they observe the rules of commensality and social distance with other ethnic groups [5].

\section{Status of Gond Women}

In a Gond customary society, the place of a woman was practically that of equality with the other sex. She lived her life shoulder to shoulder with the male sharing in all work, including earning of a livelihood. Most of the domestic work centered round her. She looked after the children, reared livestock, cooked food for the family. In all the major issues in the family, the husband consulted his wife and often honoured her opinions. [6] A woman was excluded from certain ritual observances. Despite all these, the Gond woman enjoyed a respectable status in the society because she played an important role both in production and reproduction process. [7] However, in present days her position is deteriorating with the changing globalised circumstances.

\section{Marriage System}

There existed various type of marriages in the traditional Gond society, like Ostasana Marmi (Regular), Lamsena or Lamhade Marmi (by Service), Kotavalda or Ata sata (by Exchange), Poyse Ottur or Kals Ottur (by capture), Arwitana /Harvititur or Haiwar Marmi (by Elopement), Haiwark wat/Paitu or Odiyattur Marmi (by Intrusion), Pat or Tiks Tasana Marmi (Adult or Widow Marriage), Yer Dosana Marmi (Bhul Bihao) etc. [8] Among the Gonds marriage was forbidden between blood relatives. Apart from the wishes of the boy and girl, receiving the consent of the father and mother was paramount. The Raj Gonds, the ruling Gonds, married according to Hindu customs, while in the common Gonds the marriage ceremonies were conducted by doshi, or Baiga. An important aspect of marriage system was bride price. Widow marriage was allowed in the Gond society. Their marriage systems were also pro-women. Remarriage, divorce systems are not clumsy but simple and easy to follow. The position of polygamy among the Gonds no longer exists now. At present Gonds consider monogamy as an ideal form, and resort to polygamy in certain unavoidable circumstances. Moreover, the Gonds now disassociate themselves from the marriages by capture, intrusion and elopement, and consider these anti-socials. They admire marriage by proper settlement and all of them participate in it most cordially. Cross-cousin marriages are still prevalent in Gond society.

\section{RELIGIOUS LIFE OF THE GONDS}

Traditionally the Gonds are polytheistic and followers of animism and Nature worship. Their religion is deeply rooted in them and it still occupies a pivotal position in uniting them to live as a compact social group by conditioning the various human behaviours, habits, activities, feelings and thought. But the religion has been under the influence of the socio-religious complex of Hinduism, and has therefore been constantly changing in the light.

\section{A. Gods and Goddesses}

The Gonds had many Gods and Goddesses in whom they firmly believed. It was extremely rare to find any representation of the Gond Gods. The chief animistic Gods of the Gonds of East Vidarbha were as follows: Bhagvan ( the Creator), Bara-Pen, Budhalpen, Phersapen (the great God) Mahadeo, Dulha Pen (Bride-groom God), Ghansam or Bagroom-Pen (tiger God), Hardul Pen (God of cholera and wedding), Kuwara Bhivsen, Nat Awal, Thakur Pen, Hulera Pen, Matiya-Pen, Narayan-Pen, Koya-Pen, Maswasi-Pen, 
Kanya, Marai Mata, Darti Mata (Mother earth Goddess) etc. [9] A special characteristic of Gond Gods is that they die and again born. As a result of contact, observation, imitation and emulation of religious imaginations, emotions of Hindu caste people, the Gonds have suitably integrated the doctrines of Hindu religion - on Dharma and Karma, transmission of soul and its re-birth, existence of Swarga (heaven) and Narka (hell) in the Almighty kingdom, Puniya (merit) and papa (sin), cult of Shudh (sacred) and Ashudh (profane) - with their traditional beliefs and faiths.

\section{B. Festivals of Gonds}

There were several religious festivals of the Gonds. These were Akhari, Jiwati, Pola, Diwali Nawo tindana, Dussera, and Phag or Shimga festivals. [10] Many of them were connected with agricultural season. The Gond festivals were collective rituals. They were celebrated with great zeal and enthusiasm. The logic behind of celebrating festivals was nearly same all over the middle India. However, with influence of Hinduism and other religions the basic ingredients of the festivals changed to some extent. Today, they celebrate Hindu festivals like Ganesh Chaturthi, Raksha-bandhan, nagpanchmi, diwali, dashara, holi with the same enthusiasm as that of the Hindus.

\section{Concept of Death}

The Gonds had their own concept of death. The funeral rites were part of the metaphysical significance that the death occupied an important occurrence in the birth-life-death cycle. Initially the burial was only practiced by the Gonds, however the ruling classes had started cremation and since then both burial and cremation practiced. [11] The funeral rites related more to the passage of the soul to the world of spirits. However, there were special rights for uncertain deaths that occurred in Gond society. Among the Gond mythology, the dead were believed to be greatly interested in the affairs of the living. There was a keen desire to maintain contact and to solicit the presence of the dead to minimize the difficulties of the living, and to help to bring rain and aid the crops to thrive. In the underworld the soul, enjoyed the same status as they were on the earth and led the same desire for thing they owned here. [12] Therefore, it was customary to offer worldly possession of man either inside or on the top of graveyard when a person died. He was also remembered on festive occasions. Thus the Gonds believed in life after death.

\section{Cultural Practices of the Gonds}

The Gonds had evolved their own cultural practices in the process of their social formation, without much interaction with the other culture. Their cultural practices were simple and had been translated through generation to generation by means of oral tradition.

\section{A. Food}

The food habit of the ordinary Gond was somewhat uniform. They were habituated to take three meals in a day. The technique of cooking a meal included frying, boiling, baking and roasting. Their staple food was the gruel of millet and rice boiled in water. Another common dish was the broth or juice of millet. In times of scarcity, the dried flowers of mahuwa were mixed into the gruel. They were generally meat eaters and ate the meat of any kind of animal, excluding totem animal. The prohibitory forest laws, debarring explorations of the forest in quest of food have led the Gonds to develop their agricultural and to move into labourers jobs. Frequent contacts with market centers and other cultural groups have also influenced their traditional food habits. There has thus been continuous change in their food habits, in their culinary art, their meal pattern, and in the stimulants they take. The culinary art has been gently reformed; the use of edible oil and spices has increased greatly than in the past. The gruel (Pej) is still a constant food, but it is supplemented to a great extent with chapatis, boiled rice, pulses and vegetables, instead of forest food such as edible roots, tubers, fruits and flowers and the flesh of animals and birds.

They generally indulged in drinking liquor distilled from mahuwa flowers. [13] It was not only a welcome stimulant, but also an important ingredient in their religious and social ritual. It was essential for every offering; it was consumed in large quantities during weddings and funeral feasts; it was also indispensable at caste dinners. Consumption of liquor was never considered a social evil but was accepted as a social lubricant which develops the spirit of togetherness and feeling of oneness among the Gonds. [14] Drinking liquor and smoking tobacco in the clay-pipe were reported as traditional. But now the former is affected by the ban on self-distillation; the latter has been affected by the bidi. Now the Gonds smoke tobacco or bidi several times a day instead of drinking liquor in excess.

\section{B. Clothing and Ornaments}

The male members of Gond society wore dhotis that came up to their knees, a vest, and shawl over the shoulder and a turban on their head. [15] They wore silver bangles on their wrists, wearing bangles was a sign of good fortune, a locket around their neck and earrings. The women wore six to eight yard saris reaching to the knees and tied with a belt. The women loved jewellery. The ornaments were not only meant for aesthetic purpose but they were also protective gadgets. [16] They also tattooed their bodies. Tattoos were seen as true jewellery that remained with the women even after they died and were said to please the Gods. The women believed that tattooing beautified the body as well as made it healthy. [17] However, the aesthetic, cultural and magical values, connected with the traditional dress, ornaments and tattoo marks, are also fast disappearing due to the pervasive interaction with other cultural groups through market centres, town and developmental activities. Partial nudism no longer prevails, and the extensive use of ornaments and tattoo marks in place of clothing no longer exists, as in the past. Now in place of lion-cloth, half-long cloth(lungi) to cover the waist, old fashioned half-shirt, and backless bodice(choli) to cover the torso, modern dresses purchased ready-made from weekly markets and towns are worn. Males wear full-sized long-cloths and shirts and women wear coloured eight yards of long cloth and blouses to cover most of themselves.

The modern type of coats, jackets, sweaters, mufflers and saris are worn as ceremonial dresses of marriages, festivals and fairs. The women admire ornaments made of silver and 
gold but wear them more sparsely than in the past. Tattooing is neither considered important to decorate the body nor to express religious and magical values. Young girls dislike large number of tattoo marks on their bodies and they get tattooed tribal identification marks on their face and a few marks on their wrists, etc. just to add to their beauty - unlike the aged women on their bodies. Thus, the aesthetic, religious, cultural and magical sense and values, the concepts of beauty and elegance in terms of animism, and simple life, which used to be exhibited through clothing, ornaments and tattooing, have faded from among the Gonds in the dynastic process of change.

\section{Songs and Dances}

Songs and dances accompanied by musical instrument played an important role in the lives of the Gonds. The main dances were Karma, Ri-na, Ri-lo, Re-la, Sela-Danda (stick), Mandari, Hulki, and Suwa etc. These were accompanied by various musical instruments like, drums, kikir, flute, cymbals and others. [18] It is through the songs and dances the Gonds sought to satisfy their inner urge for revealing their soul. The dance movements were very fast in many forms which keep them physically fit. Even the rhythm played on instruments is of quite high note which regulate their activities. Their songs had rare beauty and deep simplicity. Music and dance had been a tradition since time immemorial. However, now the songs sung in the villages are also composed in the Hindustani-lingua-franca, and the Gondi songs have become little known to the Gonds. The acculturation, led by the dances and songs of cinema and natak-mandalis of the region has resulted in the fast disappearance of traditional songs and dances.

\section{Art and Craft}

The Gonds were expert in arts and crafts. They were also expert in beautiful wall paintings and floral designs that depicted geometric designs and stylistic figures of plants and animals on the walls of their houses. They were masters in the art of personal decoration. Thus, those were of the values in Gond culture, which were worth preserving. The geometric and symbolic designs carved on wall and door, on comb and tobacco-case were thousands of years old, going right back to the ancient civilization of the Indus Valley. [19] However, a colourful drawing on walls is a fast disappearing feature due to urban influence. Now the walls are decorated with framed or unframed pictures of Hindu deities, national leaders, cinema stars, animals and birds which are purchased from weekly market centres and towns.

\section{E. Gothul Institution}

The traditional Gotul institutions of the Gonds had inculcated a sense of discipline and co-operative endeavor among their members. It was not just a club for meeting the boys and girls at night, as it was focused by some scholars. [20] It was the centre of learning and had a religious affiliation to it. When there were no educational institutions available to the Gond community the Gotul was functioning like training centre. It inculcated the integrity and uniqueness among all the members of the Gotul. However, with the time changes, the Britishers destroyed Gotul system as they considered them as center for conspiracy against them.
Today it lost its originality and existence.

\section{F. Gondi Language}

The language spoken by the Gonds in their daily life was Gondi. Gondi is spoken in six Indian states- Madhya Pradesh, Maharashtra, Chhattishgarh, Andhra Pradesh, Telengana and Odisha-by around five million people. The mother tongue Gondi belonged to Indo-Dravidian family of languages. The inter group communication of Gonds was purely in their own mother tongue. But when they communicated with outsiders they used mixed type of colloquial Hindi, called as Chhattisgarhi in Madhya Pradesh. Gondi lingers only as a relic of the aged Gonds. The children and the young adult are able to speak or understand Gondi well. According to the 1991 and 2001 censuses put the figure of Gondi language speakers at 2.1 and 2.7 million respectively. But there is a big area of Gondi speakers under maoist control where no census is done, so realistic number should be higher than government figures. [21] This census figure includes Dorli, Ganda, Maria and Muria in Andhra Pradesh, Madhya Pradesh, Maharashtra and Orissa. Gondi is one of the Non-scheduled languages spoken in India mainly in its central part, i.e., in Madhya Pradesh and in the adjoining states of Andhra Pradesh and Maharashtra.

\section{CONCLUSION}

Hitherto it has become customary to assume safely that the interaction led by the urbanization, modernization, Hinduism, etc, after independence has resulted in a great deal of change in the traditional life of the Gonds. In urban areas now it is difficult to distinguish between the Gonds and the non-Gonds at social gatherings. The Gonds have suitably accommodated a number of things in their household articles, human attires, food habits and personal hygiene's. Their endeavour to adapt new has made significant changes in their traditions, customs, values, and religious beliefs and rites, in the light of the Hindu way of life. Once upon a time the Gonds were the most cultured community. However, many of them are living in poverty today. They have lost their royalty to paramount powers. They were good looking, happy and hearty and regular in their habits. Though financially not very sound but they managed their affairs without getting indebted. They observed perfect gender equality and attempted to keep their tribe widow free. No highhandness is found in their behaviour. They were docile, modest, honest and painstaking. Loyalty to their tribe, traditions, systems, organizations is praiseworthy and worth to be followed by elite class. Still the Gonds posses the same spirit and truthfulness as it was in the past. What great tribute would be given to these tribes?

\section{REFERENCES}

[1] Census of India, Government of India, 2011.

[2] Aparna Pallavi. The Gond Kingdoms. [Online] Available: http://www.downtoearth.org.in

[3] J. N. Sil, History of the Central Provinces and Berar, Calcutta: Babu Jogendra Nath Sil, from Seoni, C.P., 1917, p. 63

[4] K. Gough, "The origin of the family," Journal of Marriage and the family, 1971, vol. 33, no. 4, pp. 760-771.

[5] S. Fuchs, Gond and Bhumia of Eastern Mandla, Mumbai: Asia Publishing House, 1960, p. 20.

[6] V. Elwin, A New deal for Tribal India, London: Ministry of Home Affairs, Government of India, 1963, p. 6. 
[7] L. Dube, "The Gond women,” Ph.D. Dissertation, Nagpur University Library, Nagpur, 1949, p. 343.

[8] H. H. Risley, The Tribes and Castes of Bengal, Calcutta: OUP, 1891, vol. 1, p. 88

[9] Captain Ward, Report on the Land Revenue Settlement of Mandla District, Central Provinces, 1868-1869, p. 133.

[10] Furer-Haimendorf, The Gonds of Andhra Pradesh, New Delhi: Vikas Publishing House, 1979, p. 452

[11] Furer-Haimendorf, The Gonds of Andhra Pradesh, New Delhi: Vikas Publishing House, 1979, p. 368.

[12] Furer-Haimendorf, The Afterlife in Indian Tribal Belief, Royal Anthropological Institute of Great Britain and Ireland, 1952, vol. 83, no. 1, p. 38 .

[13] I. Singh, Gondwana and the Gonds, Lucknow: The Universal Pub., 1944, p. 21.

[14] V. Elwin, The Baiga, London: John Muuay, 1939, p. 44

[15] R. Temple, Hislop, Papers Relating to the Aboriginal Tribes of the Central Provinces, Appendix VII, 1866, p. XIII.

[16] K. N. Thusu, "Gond kingdom of Chanda," Archaeological Survey, India, Delhi, 1980, p. 40.

[17] S. Fuchs, Gond and Bhumia of Eastern Mandla, Mumbai: Asia Publishing House, 1960, p. 61

[18] V. Elwin, Tribal World of Verrier Elwin, London: OUP, 1964, pp. 103-104.

[19] V. Elwin, The Tribal Art of Middle India, London: OUP, 1949, p. 6.

[20] V. Elwin, The Muria and their Ghotul, Bombay: OUP, 1947, p. 34.

[21] Aparna Pallavi. Language is the only tool for expressing identity and culture. [Online]. p. 46695. Available: http://www.downtoearth.org.in
Shamrao I. Koreti is an assistant professor of Post Graduate Teaching Department of History, Rashtrasant Tukadoji Maharaj Nagpur University, Nagpur. He is specialized in modern Indian history, tribal history and culture, economic history of India, Maratha history etc.

He was born in 1975, and was awarded a national scholarship for securing merit percentage in $12^{\text {th }}$ STD from CBSC, Delhi Board. He completed his graduation from Vasantrao Naik Institute of Social Sciences, (old Morris College) Nagpur in 1997. He also did graduation in law in 2000 and simultaneously did his masters in history in 1999 as an external student. He then cleared NET examination twice in 1999 \& 2000. He did Ph.D. in 'Socio-cultural history of the Gonds of Madhya Pradesh' in 2011. His Ph.D was published in book form in 2013 .

After clearing NET examination he was appointed as a lecturer at Bharatiya Mahavidyalaya Morshi in 2000. He worked there till 2003. And since June 2003 he is working as an assistant professor at the Department of History, Rashtrasant Tukadoji Maharaj Nagpur University, Nagpur, India.

$\mathrm{He}$ is a life member of Indian History Congress, life member of Indian National Trust for Art and Cultural Heritage, life member of Interdisciplinary Policy Research and Action, life member of Akhil Maharashtra Itihas Parisad, life member of Society of South Asian Archaeology.

$\mathrm{He}$ is also engaged in several other academic and administrative endeavours. $\mathrm{He}$ is also credited with three books published and 18 papers published in both national and international journals. He is also an editorial member of two journals. And he is guiding seven Ph.D students under his supervision. 